\title{
Utilizing inquiry-driven science outreach to curate Natural Trap Cave fossils and inspire the pursuit of STEM careers
}

Cory M. Redman ${ }^{*}$ (D), Susumu Tomiya ${ }^{2,4}$, Kathleen Bitterman ${ }^{2}$, Kacia Cain ${ }^{3}$ and Julie A. Meachen ${ }^{2}$

\begin{abstract}
Despite the rising emphasis on STEM (science, technology, engineering, and mathematics) education in the last two decades, the United States has seen little change in student performance, based on international assessments. Transforming science education from the more traditional, lecture-format classes to inquiry-driven exercises is central for improving student's STEM literacy and competency at all grade levels. This paper describes an outreach program that was developed for upper-level U.S. high school students (10th-12th grade) and centers around hands-on, inquirydriven exercises using the large-bodied (>3 kg) mammalian fossils from Natural Trap Cave (NTC). The objectives of this program were for the students to develop an understanding of the morphological adaptations of the vertebrate skeleton, preservational biases in the fossil record, and to participate in each of the curatorial steps used for the longterm preservation of fossils. Students from Des Moines Public School Central Campus came to Des Moines University 2 hours a week for a semester, receiving high school and community college credit for participating. The NTC outreach program has been offered for 11 semesters since the fall of 2014. Thirty-four high school students have participated, consisting of 24 women and 10 men, with 19 of the students belonging to African American, Middle Eastern, Asian, and Hispanic ethnicities. The students helped to identify and curate 3,700 NTC fossil specimens. Several of the students presented posters on the work they did during this outreach program at the multiple district and state science fairs in lowa and received accolades. Only the 2017-2019 students were surveyed, but all the students reported gaining a deeper understanding of the scientific process and the utility of paleontology. One student even reported changing their career goal from undecided to a STEM field. The framework developed for the NTC outreach program can be easily modified to fit the needs or structure of another research project, community partnership, science laboratory, or museum facility, with the target audience being students from middle school to undergraduate. This type of STEM outreach program can also help improve scientific literacy and generate much-needed excitement and interest in science, at a time when many students are exploring potential career paths.
\end{abstract}

Keywords: Paleontology, Natural history collections, Collections care, Inquiry-driven exercise, Student research

\section{Introduction}

Addressing challenges of the twenty-first century (e.g., climate change, loss of biodiversity, food security, new pathogens, environmentally induced health issues)

\footnotetext{
*Correspondence: corymredman@gmail.com

${ }^{1}$ Grand Rapids Public Museum, Grand Rapids, MI 49504, USA

Full list of author information is available at the end of the article
}

requires a competent STEM (science, technology, engineering, and mathematics) workforce, composed of scientists, engineers, policymakers, and the public, who recognize the gravity of these challenges and can devise creative solutions. This can only be achieved through the significant integration of STEM disciplines into K-16 education (Brewer and Smith 2011; Cook et al. 2014; Grant et al. 2017; Haak et al. 2011; Honey et al. 2014; original author(s) and the source, provide a link to the Creative Commons licence, and indicate if changes were made. The images or other third party material in this article are included in the article's Creative Commons licence, unless indicated otherwise in a credit line to the material. If material is not included in the article's Creative Commons licence and your intended use is not permitted by statutory regulation or exceeds the permitted use, you will need to obtain permission directly from the copyright holder. To view a copy of this licence, visit http://creativecommons.org/licenses/by/4.0/. The Creative Commons Public Domain Dedication waiver (http://creativeco mmons.org/publicdomain/zero/1.0/) applies to the data made available in this article, unless otherwise stated in a credit line to the data. 
Jarrett and Burnley 2003; Maltese et al. 2014; National Research Council 2012; Nazier 1993; Potvin and Hasni 2014). Despite the rising emphasis on STEM education in the last two decades, the United States has seen little change in student performance, based on international assessments. The United States' TIMSS (Trends in International Mathematics and Science Assessment) and the PISA (Program for International Student Assessment) scores have not changed significantly since these assessments were first implemented in 1995 and 2000, respectively (Schleicher 2019; TIMSS 2019). TIMSS' 2019 assessment ranked U.S. fourth graders eighth among the 64 participating education systems and U.S. eighth graders ranked eleventh among the 46 participating education systems. Both grades had an average score that was not statistically different from nine other educational systems (TIMSS 2019). PISA's 2018 assessment ranked U.S. 15-year-old students ( 10 th grade), 36th out of the 78 participating countries, with their average score not being statistically different from 12 other countries (Schleicher 2019). STEM outreach programs can help address this issue, increasing STEM literacy and excitement in the U.S. at all age levels.

Transforming science education from the more traditional, lecture-format classes to inquiry-driven exercises has emerged as a central theme to improve student performance at all grade levels (K-16; Freeman et al. 2014; Grant et al. 2017; Haak et al. 2011; Handelsman et al. 2004; Kelly and Visaggi 2012; Kontra et al. 2015; Next Generation Science Standards 2013; Olcott 2018; Winstone and Milward 2012). Active, inquiry-driven exercises increase students' knowledge retention, because they are shaping the progression and outcomes of an exercise. Inquiry-driven exercises provide students with a question (or allow them to create their own), generate predictions, develop hypotheses, gather relevant data from physical specimens or online databases, and conduct analyses to test their hypotheses (e.g., Cook et al. 2014; Grant et al. 2017). This exposes students to key concepts and relates more abstract concepts (e.g., evolutionary theory) to real world examples, while engaging with the scientific method and the process of discovery.

The positive impact of inquiry-driven exercises centered around physical specimens (e.g., fossils) is significant (Cunningham 2021; Haak et al. 2011; Kontra et al. 2015; Maltese et al. 2014; Suarez and Tsutsui 2004). Physical specimens provide a tactile focal point for questions, concepts, and data. For many students, specimen-based learning encourages their curiosity, drawing upon their personal interests, and can engage students who may not normally be an active classroom participant or have different learning styles, including those with limited English proficiency. Such experiences increase the prospect of recruiting underrepresented groups into STEM fields (Hughes 2018; Meyer et al. 2012; Sadler et al. 2012; Smith-Doerr et al. 2017; Visaggi 2020; Wang and Degol 2017).

This paper describes an outreach program that was developed for upper-level U.S. high school students (10th-12th grade) and centered around hands-on, inquiry-driven exercises using the disarticulated, largebodied $(>3 \mathrm{~kg}$ ) mammalian fossils from Natural Trap Cave (NTC). NTC is a well-known Quaternary (i.e., Ice Age) fossil locality located in the Big Horn Basin of Wyoming (Martin and Gilbert 1978; Fig. 1). This outreach program was developed in conjunction with a concurrent paleontological research project on NTC. The active research project examines how late Pleistocene warming events may have precipitated genetic and morphological changes in North American mammals whose remains had been preserved in the cave (e.g., Meachen et al. 2016; Tomiya and Meachen 2018). The goal of the outreach program was to increase public high-school students' exposure to evolutionary and whole organismal biology and geology and provide them with the opportunity to participate in paleontological research and collections care. Additional goals of the program were to increase excitement and interest in science, at a time when many students are exploring potential career paths, raising awareness about the necessity for natural history collections, and addressing student misconceptions about science and the scientific method.

\section{Methods}

All of the vertebrate fossils used in this outreach program came from NTC. NTC is a pitfall trap, with its only entrance consisting of a $24.5 \mathrm{~m}(80 \mathrm{ft})$ drop. NTC is an important fossil locality that produces a wealth of disarticulated, large- and small-bodied vertebrates and pollen from the late Pleistocene and early Holocene epochs (Wang and Martin 1993). Fossil excavations in NTC have been conducted by multiple teams of scientists starting in 1969 (Rushin 1973), with the most recent excavations starting in 2014, by a team of international researchers, led by Julie Meachen of Des Moines University (DMU). NTC has yielded 18 large-bodied mammal species $(>3 \mathrm{~kg})$, including many of the charismatic species (e.g., mammoths) associated with the last Ice Age (Table 1). NTC's large-bodied mammalian assemblage was the focus of the inquiry-driven exercises developed for the high school outreach program reported here. The objectives of the program were to introduce students to the form and function of the vertebrate skeleton, participate in each of the curatorial steps used for the long-term preservation of fossils, and conduct statistical analyses to test for preservational biases in NTC's fossil assemblage 


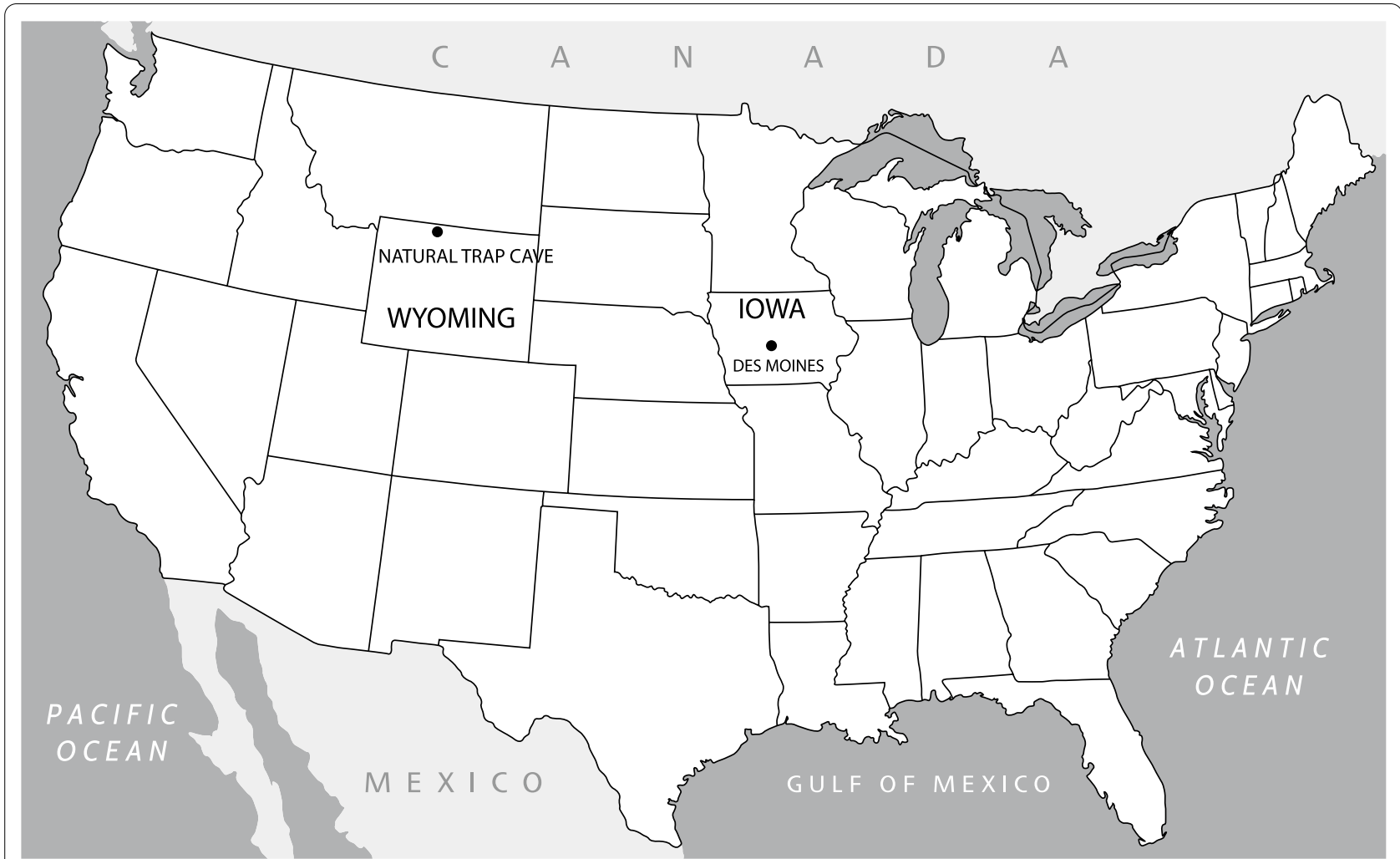

Fig. 1 Map of the USA showing the location of Natural Trap Cave in relation to Des Moines, lowa

Table 1 Species and common names of the large-bodied (>3 kg) mammals found in Natural Trap Cave

\author{
Mammuthus sp. (Mammoth) \\ Camelops sp. (Camel) \\ Equus sp. (Caballine horse) \\ Haringtonhippus sp. (Stilt-legged horse) \\ Bootherium bombifrons (Musk ox) \\ Bison antiquus and Bison bison (Bison) \\ Ovis canadensis (Bighorn sheep) \\ Antilocapra americana (Pronghorn) \\ Arctodus simus (Short-faced bear) \\ Panthera atrox (American lion) \\ Miracinonyx trumani (American cheetah-like cat) \\ Canis cf. lupus (Beringian wolf) \\ Canis latrans (Coyote) \\ Aenocyon dirus (Dire wolf) \\ Gulo gulo (Wolverine) \\ Vulpes vulpes (Red fox) \\ Lynx sp. (Lynx and/or Bobcat)
}

that could affect paleontological interpretations. The learning objectives each semester were determined by the need or progression of the NTC research project. For example, skeletal morphology and fossil curation were the focus early on, because there were large field collections that needed to be identified and curated. As the data set increased, students switched from an emphasis on fossil curation to taphonomic (the process of burial and preservation or destruction) analyses of NTC's fossil assemblage.

The NTC outreach program was a collaboration between J. Meachen's research team at DMU and Kacia Cain, a biology teacher at Des Moines Public School Central Campus (PSCC) and most recently at Winterset High School. The instructors of this program consisted of C. Redman (postdoctoral researcher with 8 years of experience supervising students in a laboratory setting), S. Tomiya (postdoctoral researcher with 9 years of prior curatorial experience, including supervising high school student interns), K. Bitterman (lab manager with 9 years of prior experience as an instructor in similar outreach programs), and J. Meachen (Principal Investigator of the NTC research project and a tenured Associate Professor with 20 years of experience in mammalian morphology). Student recruitment began at the start of a semester, with J. Meachen giving in-class presentations to K. Cain's upper-level science classes. The forty-minute presentations outlined the ongoing NTC research project and 
how the students would be contributing to the project. Interested students were required to write a one-page essay explaining why they wanted to participate in the program and why they thought they would be an asset to the project. Based on the essays and consultation with $\mathrm{K}$. Cain, students were accepted into the outreach program for one semester, with the opportunity to re-enroll for subsequent semesters if space was available. PSCC determined that students would earn 1 hour of high school and community college credit in independent study each semester, provided they had minimal absences and kept weekly journal entries.

Up to six students were accepted into the outreach program every semester, with the limiting factors being lab space and the number of instructors available. Students participating in the outreach program came to Des Moines University campus 2 hours per week after school or Wednesday afternoons to work with the NTC fossils in J. Meachen's lab. DMU and PSCC are in close proximity to each other ( $1.6 \mathrm{~km}$ or 14 city blocks), so students were required to find their own means of transportation to DMU. Students walked, carpooled, or took the city bus. DMU parking permits were provided to students who drove, and the city bus was free with a student ID. From the instructors' perspective, it was easier having the students come to DMU than having to pack up a subset of NTC fossils, extant comparative material, and any hard-copy references to take to PSCC. Having the students come to DMU and work in an active research lab also provided a unique, immersive learning experience and reflected the atmosphere of a professional internship.

At the start of each semester, admitted students were given a broad overview of the program's structure, student expectations, and proper lab etiquette and handling of fossils. Every student was given a lab notebook for taking notes, doing anatomical drawings (Fig. 2), and their weekly reflections. The high school students that participated in the NTC outreach program had little to no background in zoology, paleontology, Earth sciences, museum curation, or anatomy, so our inquiry-driven exercises were designed to teach fundamentals. To understand the form and function of the vertebrate skeleton, students would dedicate a significant portion of their time to learning comparative skeletal morphology, including the terms used for anatomical directions. Instructors would introduce one skeletal region at a time (e.g., upper limb) for the students to explore, giving a brief overview $(<30 \mathrm{~min})$ of bone names and their skeletal position and orientation. Students would pair up and be given 2-4 human bones that did not articulate but came from the same body region. The students would work together to identify all the bones, determining their position and orientation, sketch the bones, and come up with multiple features that could be used for identification. Introductory human anatomy textbooks and an articulated human skeleton were provided for reference. Once a student pair had correctly identified their bones, each student would take turns teaching their peers about the morphological features that could be used for identification, leading to a student-driven discussion about which morphological features are diagnostic for different bones. Complete bones from the human skeleton were used to introduce skeletal anatomy, so students could reference their own body.

Once the students became familiar with the human skeleton, they were introduced to skeletal elements of various extant species (e.g., dog, cat, horse) that were closely related to the fossil taxa found in NTC. With this comparative material, we discussed skeletal adaptations for different locomotor habits and diets. Student pairs were then given NTC fossils to focus on finer morphological details. Sometimes they were told what species the bones came from and sometimes they would have to figure that out. The goal of these exercises was not for every student to handle every bone from each taxon found in NTC, but for the students to develop a system of identification that worked for them. Instructors recommended that students set up a simple method of elimination (e.g., starting with body size), but each student was left to design their own system. Occasionally, the students' knowledge would be tested using fun, game-show type activities (e.g., Pictionary), with students winning candy for correct answers. The goal of these games was to reinforce concepts and help students improve their scientific observation and critical thinking skills.

As the students became more confident and accurate in their bone and taxon identification, they were given the more complete skeletal elements recovered from NTC and asked to verify the field ID of the bone and taxon (Fig. 3). Identifying the more difficult or incomplete skeletal elements from NTC, were given to the students towards the end of the semester, so they did not get discouraged and had a knowledge base to draw from. To help identify the taxa from NTC, students had access to comparative skeletal guidebooks (Table 2), scientific articles, online resources, and disarticulated skeletons from related extant taxa. Having a complete skeleton of each species or a closely related taxon (e.g., an African lion skeleton for an American lion) found in NTC would have been ideal, but was not possible, so the students had to rely on the other resources provided. All students' skeletal and taxonomic identification were checked by an instructor before it was entered into a provisional collection spreadsheet.

The high school students involved in the NTC outreach program also performed each of the steps used in the 
Redman et al. Evo Ed Outreach

(2021) $14: 13$

Page 5 of 10

Femur, Tibia, Metatarsal

Refreshing -Deer (Odocoileus virginians) ol/delis tibia $\rightarrow$ triangle "sharp" ridge of shin is shaped like a triangle

To Hell if femur is $R$ or L: divot in back. (door are backwoods?)

Identifying a femur:
shaped like an $\mathrm{F}$

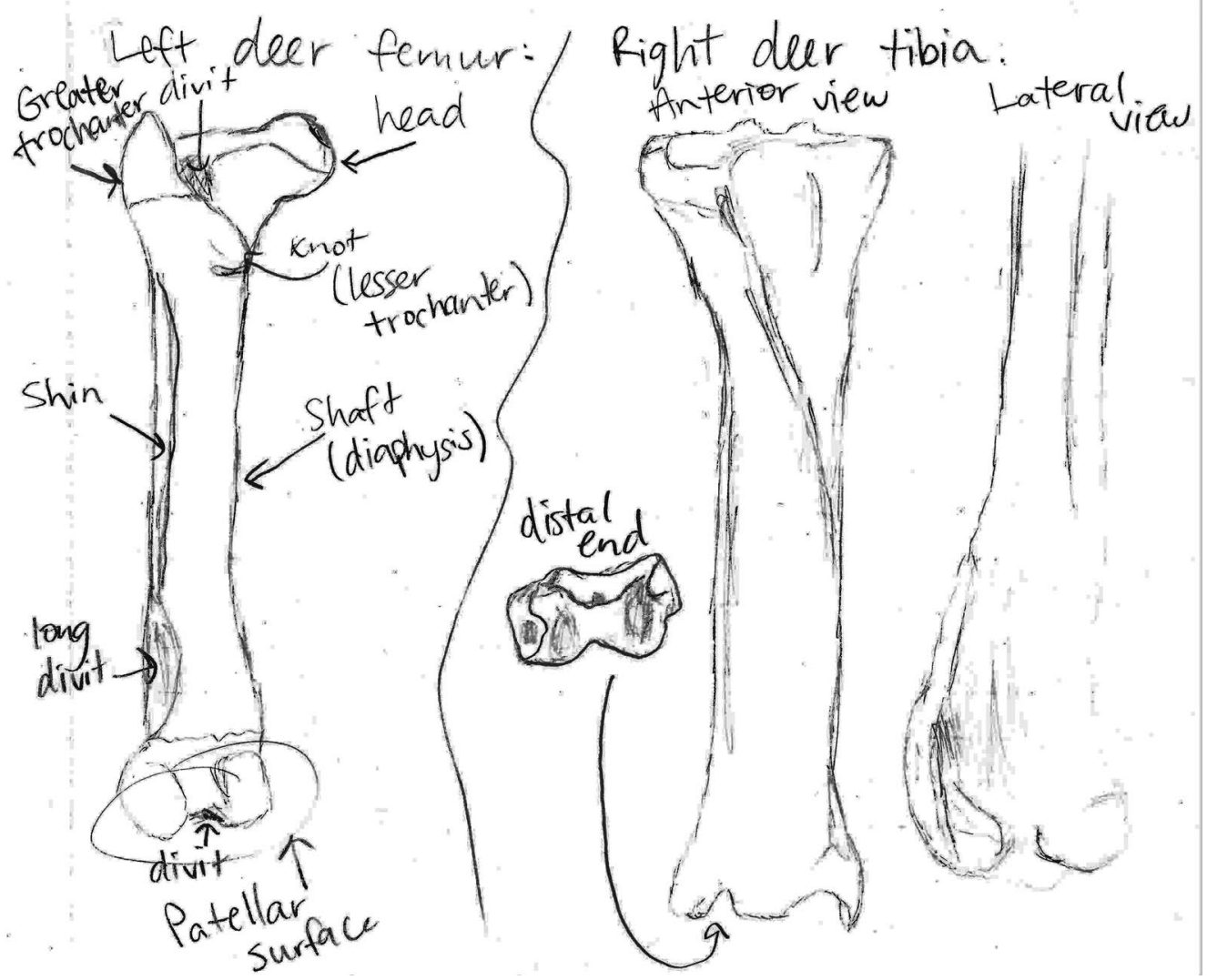

Fig. 2 An example of an anatomical drawing from a student's notebook

curation and long-term preservation of fossils (Fig. 4). These steps included: basic specimen preparation, identification, photography, and data entry. These tasks were not done by the students in any particular order, but depended on the need of the ongoing NTC research project. Proper techniques for handling fossils to minimize accidental damage (e.g., dropping a fossil) and never separating a fossil from its data sheet, were ingrained into all the students at the start of the semester. Proper curation techniques were taught through demonstration. Instructors would show a student or a student pair the proper technique and once the students had mastered 


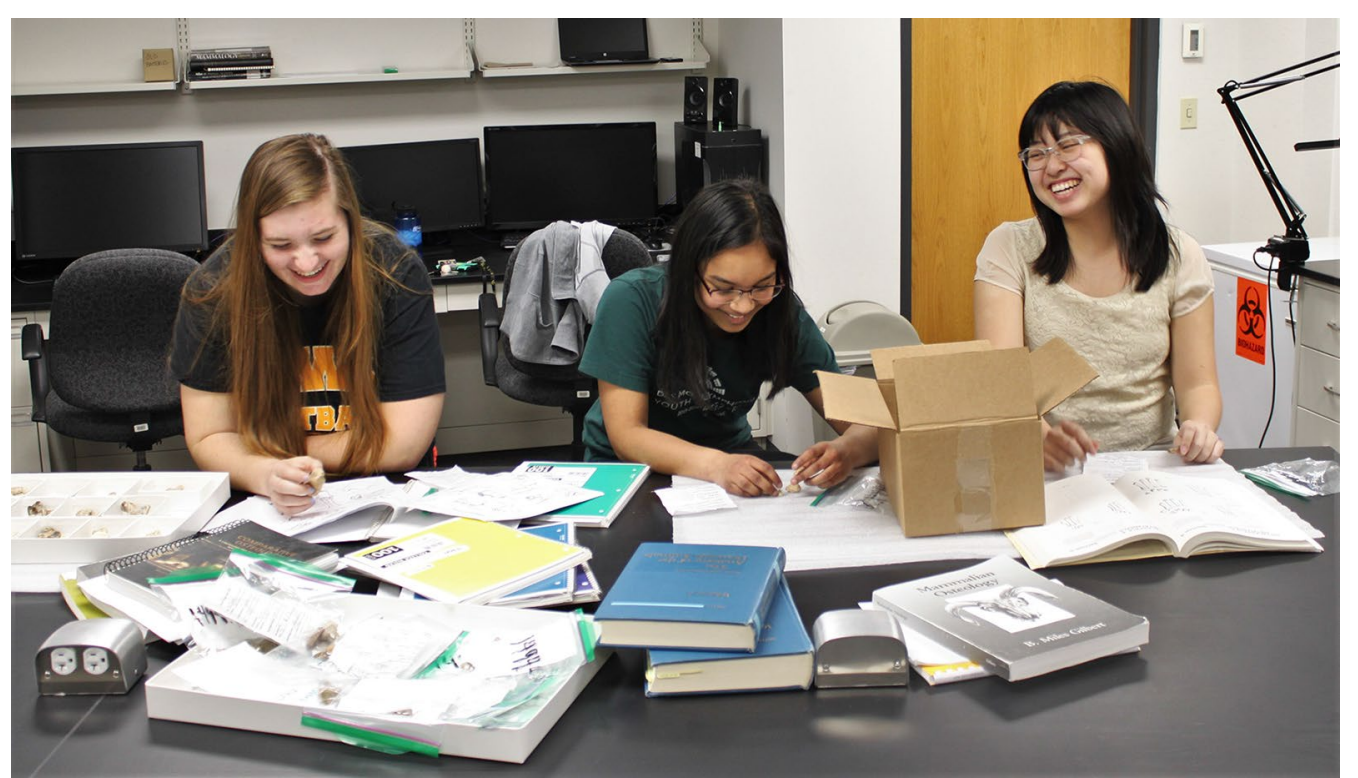

Fig. 3 Students identifying Natural Trap Cave fossils

Table 2 A list of the core comparative skeletal guidebooks used in this outreach program

A Guide to Post-cranial Bones of East African Animals, by Rikki Walker (1985)

Bone Guide to Selected Land Mammals of the Northwestern States, by Lee Post (2016)

Comparative Osteology: A Laboratory and Field Guide of Common North American Animals, by Bradley Adams and Pam Crabtree (2011) Mammalian Osteology, by B. Miles Gilbert (2003)

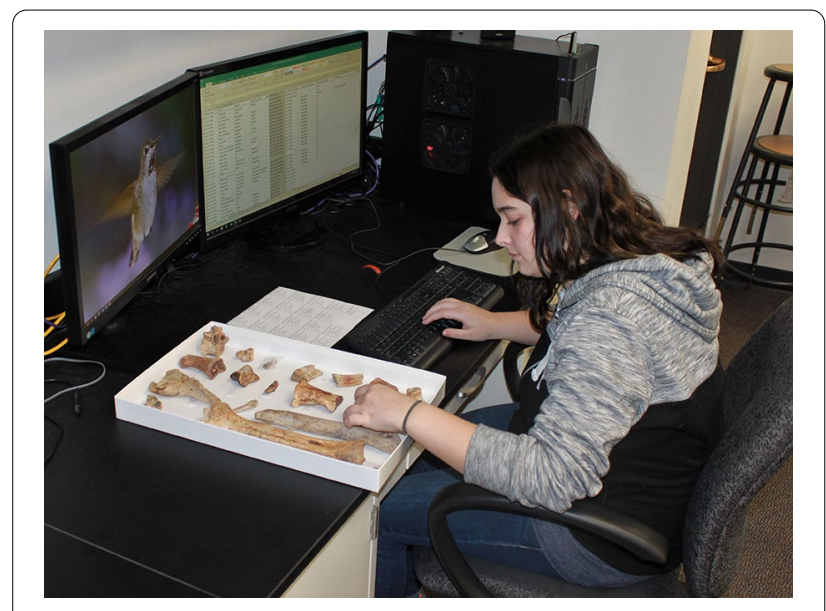

Fig. 4 A student doing basic specimen data entry

the technique, they would teach their peers. The fossils recovered from NTC are typically incomplete and have experienced various degrees of water saturation, but little to no weathering. Fossil preparation usually consisted of using a damp toothbrush to gently clean the bone of any matrix, letting the specimen air-dry, and then applying any adhesive (Paraloid B-72 in acetone) to repair breakages. Several specimens in small plaster jackets have been collected from NTC, but these were also easily prepared by students, using small paint brushes and dental picks. Students spent a majority of their time on fossil identification and would photograph any specimens that were complete or unique, so the photos could be used as a reference for future lab and field work. Photographing skeletal elements from the extinct taxa found at NTC was the priority, because the comparative material was limited. The final curation task that some of the students performed was basic data entry. Only a small number of capable, detail-oriented students performed this task, because accuracy was paramount. All the fossils collected from NTC are reposited in the University of Wyoming's (UW) Collection of Fossil Vertebrates. UW provided a Microsoft Excel spreadsheet with the required information fields needed for each specimen. Students would work in pairs filling out simple parts of this spreadsheet, one reading the information out aloud and the other entering the data. Students that did data entry started with the fossils they had identified, so they 
could continue taking ownership of their work. All of the students' data entries were also carefully checked by an instructor.

The high school students also took part in a guided research project to assess whether any preservational biases indicated predator involvement in the accumulation of NTC's large-bodied skeletal elements. In other words, did all the large-bodied vertebrates accidentally fall into the cave and die or did some skeletal elements occur in significantly higher abundances, potentially representing body parts that were dragged into the cave by carnivores? As part of the introduction to the project, students read and discussed two publications: Wang and Martin (1993) and Spencer et al. (2003). Students were given several questions to answer for each paper, to stimulate group discussion. Wang and Martin (1993) provided background information on NTC and Spencer et al. (2003) used a similar methodology that the students would be employing. For the guided research project, students used a chi-square test to analyze the relative abundance of skeletal elements recovered in 2014 and 2015, to test whether certain body parts were over-represented. This project built upon the taxon and bone identifications completed by other students earlier in the outreach program. Each student or pair of students chose a vertebrate group (i.e., carnivorans, horses, or artiodactyls) to analyze, presenting their findings to their classmates and instructors with slides. Some of the students also presented their work in a poster format at several district and state science fairs, such as the Des Moines Public Schools District Science Fair, State Science and Technology Fair of Iowa, and the Iowa Junior Academy of Science Symposium (Fig. 5), with logistic support from K. Cain. In preparation for these science fairs, K. Cain also provided opportunities for the students to practice their presentations in front of their peers at PSCC.

\section{Results}

The NTC outreach program has been offered for 11 semesters between the fall of 2014 and the spring of 2020 . Thirty-four high school students in grades 10 through 12 have participated in the program, with 13 students participating more than one semester. Student breakdown consisted of 24 women and 10 men. Nineteen of the students belonged to a minority group, including African American, Middle Eastern, Asian, and Hispanic ethnicities. With the help of the students, the NTC research project has been able to identify and curate $\sim 3700$ fossil specimens.

High school students presented their research and shared their scientific knowledge at the above-mentioned

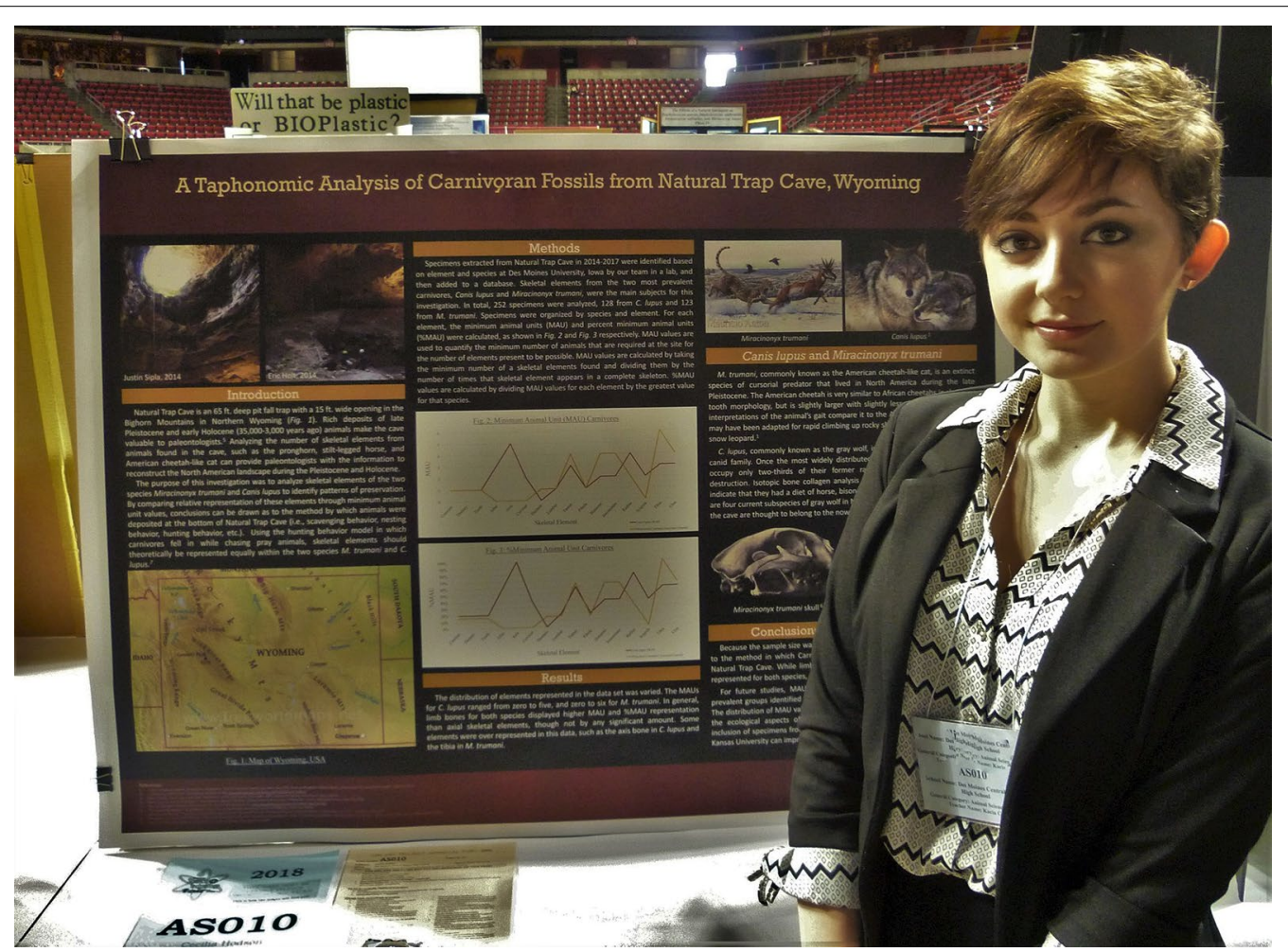

Fig. 5 A student presenting their taphonomy project at the State Science and Technology Fair of lowa 
science fairs and the Governor's 2018 Future Ready Iowa Summit. Several of the students were awarded first place, second place, and honorable mention in their respective fair categories and one student won a $\$ 500$ scholarship for her guided independent research. The Governor's 2018 Summit was composed of leaders from business and industry, educators, elected officials, and students, to discuss transforming education with a focus on expanding work-based opportunities. Students from the NTC outreach program set up a table for the summit, explaining their research and the importance of fossils and natural history collections to the attendees.

\section{Discussion}

Having a dedicated and enthusiastic high school science teacher as a community partner was essential to the success of the NTC outreach program. K. Cain's feedback for recruiting and selecting students was important, because she worked with the students on a regular basis. Carefully selecting motivated students was an important factor in the program's success. The foundational knowledge the students needed to achieve the outreach program's objectives were developed through the inquiry-driven exercises, but the students needed to come in with an interest in science. That is why J. Meachen gave in-class recruitment presentations to upper-level high school science classes. PSCC is a regional academy offering advanced, dual credit (high school and college) courses for college and career readiness to high school students in the Greater Des Moines area. The two thousand student body comes from 40 participating high schools. Enrolled students are at PSCC 2 days a week, while spending the rest of their time at their local high school. This unique structure allowed the NTC outreach program to recruit from a diverse pool of students from a relatively wide geographic area.

Only 34 students over 11 semesters participated in the NTC outreach program, because its structure requires that students receive a lot of personal instruction and guidance. It was important that we remained flexible to the diverse needs of the students, especially since they were being exposed to a lot of new information and concepts over a short period of time. If similar questions from multiple students were raised, lab activities were halted and a quick instructional or review lesson would be given on a particular topic. These short instructional lessons would use a group discussion format to continue promoting peer-learning. Taking high school students into the field would have been a component of the NTC outreach program, but the U.S. Department of Interior's Bureau of Land Management (BLM), which manages NTC, prohibits anyone under 18 years of age from entering the cave for safety and liability reasons. However, K.
Cain was able to join the NTC field expeditions in 2015 and 2016 and gain a firsthand experience in fieldwork, which enabled her to more effectively communicate the big picture of the research program to the students and support our educational mission. Other inquiry-driven exercises that were considered for the NTC outreach program included 3D scanning and modeling of fossils recovered from the cave, and having the students work on the small-bodied vertebrates (i.e., vertebrate microfossils), but these exercises have not yet been implemented.

Students that participated in the guided research component in the 2017-2018 school year were given anonymous, online survey questions at the end of the semester, including how their perception of paleontology or science had changed in general. The students' responses followed a common theme. They had not realized "all the unique real-world applications of paleontology" or that paleontology was "much more vast than [they] had previously believed" and paleontologists "do much more relevant and significant work in the science community". The students also commented that the NTC outreach program deepened their understanding or exposed them to the authentic process of scientific research in a laboratory setting. One student commented that they found scientists to be "more relatable and more down to earth" than they had expected, prior to participating in the program and regularly interacting with the instructors (i.e., scientists). Thus, the immersive learning experience in the NTC outreach program not only cleared up students' misconceptions about a particular field of science and scientists, but also made science more valuable and approachable to the students. These are fundamental steps to increasing student engagement in STEM fields. The students surveyed also expressed interest in participating in paleontological fieldwork, ancient DNA research, or studying other groups of organisms, suggesting that the inquiry-based approach of the outreach program helped ignite the participants' scientific curiosities even beyond the scope of the NTC research project.

During the 2018-2019 school year, students were surveyed before and after participating in our outreach program, in conjunction with J. Meachen's follow-up study on the Rancho La Brea Tar Pits, as one way to assess its impact on the student's knowledge and attitude towards science. The questions on the survey included: How interested are you in (1) climate change and the environment, (2) scientific research, (3) fossils and extinctions, (4) museums and natural history collections, and (5) statistics? Using a Likert scale of $1-5$, where 1 is the least interested and 5 is extremely interested, the results changed as follows: interest in climate change, the environment, and scientific research remained high at a 4.5 , interest in fossils and extinction went from a 2 to a 4.5, 
interest in natural history museums went from 1.5 to a 3.5 , and interest in statistics went from a 2.5 to a 3.5. One student even commented that their career goal changed from undecided to a STEM field. These results illustrate the positive impact the outreach program had on the student's attitude toward STEM fields. Neglecting to survey all the students that participated in the NTC outreach program was an oversight that we recommend other programs should remedy.

The framework developed for the NTC outreach program can be easily modified to fit the needs or structure of another research project, community partnership, science laboratory, or museum facility, with the target audience being middle school or undergraduate students. This type of outreach program could be used as an opportunity for graduate students to hone their teaching and mentoring skills and directly addresses the U.S. National Science Foundation's broader impact statement of societally relevant outcomes, including improving scientific literacy and recruiting underrepresented minorities in STEM. The NTC research project directly benefited from the outreach program, because the high school students helped to identify and curate 3700 fossil specimens.

\section{Conclusion}

Responding to the major challenges of the twenty-first century (e.g., climate change, rapid urbanization, environmental protections, and energy security) requires a workforce to think critically, collect and analyze relevant data, and interpret that data for the purpose of crafting creative solutions. This outreach program uses the public's fascination for fossils as a gateway to helping build a stronger STEM workforce and better-informed citizens. The NTC outreach program provided high school students with a unique, immersive experience to work with and learn from scientists in an active research laboratory for a whole semester. Students took an active role in reviewing and extracting relevant information from scientific publications, utilizing the scientific method, analyzing real-world data, conducting statistical analyses, working independently and as a team member, giving presentations, and sharing scientific knowledge in professional settings. These are transferable skill that will help a student to succeed professionally in the future, whether they choose to pursue a career in STEM or not.

\footnotetext{
Abbreviations

BLM: Bureau of land management; PSCC: Des Moines Public School Central Campus (lowa, USA); DMU: Des Moines University (lowa, USA); NTC: Natural Trap Cave (Wyoming, USA); PISA: Program for International Student Assessment; TIMSS: Trends in International Mathematics and Science Assessment; UW: University of Wyoming (Wyoming, USA).
}

\section{Acknowledgements}

We thank: Laura Vietti and Mark Clementz at UW for curatorial support and advice; Brent Breithaupt and Gretchen Hurley from the BLM for access to NTC; Desui Miao, David Burnham, Megan Sims, and K. Christopher Beard at the University of Kansas'Vertebrate Paleontology Collection and Tiffany Adrain at the University of lowa's Paleontology Repository for access to comparative specimens under their care; and two anonymous reviewers for helpful comments. We also thank all of our students who participated in this program and the NTC field crew members who contributed to fossil collection.

\section{Authors' contributions}

CMR, ST, KB, and JAM designed and implemented the education program. KC and JAM coordinated the student recruitment and provided administrative support for the program. CMR drafted and revised the manuscript. ST, KB, $\mathrm{KC}$, and JAM discussed and edited the draft manuscript. All authors read and approved the final manuscript.

\section{Funding}

NSF Grant EAR/SGP-1425059 to JAM supported the broader research project on NTC that enabled the educational program reported here. NSF Grant EAR/ SGP-1758108 to JAM supported the continuation of this outreach program. Funders had no role in the design of the study, collection, analysis, and interpretation of data, or in writing the manuscript.

\section{Availability of data and materials}

All fossil specimens were collected under BLM permit PA-13-WY-207 and are reposited at UW's Collection of Fossil Vertebrates.

\section{Declarations}

\section{Competing interests}

There are no competing interests.

\section{Author details}

${ }^{1}$ Grand Rapids Public Museum, Grand Rapids, MI 49504, USA. ²Department of Anatomy, Des Moines University, Des Moines, IA 50312, USA. ${ }^{3}$ Winterset

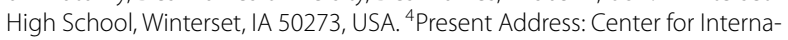
tional Collaboration and Advanced Studies in Primatology, Kyoto University Primate Research Institute, Inuyama, Aichi 484-8506, Japan.

Received: 23 April 2021 Accepted: 9 August 2021

Published online: 16 August 2021

\section{References}

Brewer CA, Smith D, editors. Vision and change in undergraduate biology education: a call to action. Washington DC: American Association for the Advancement of Sciences; 2011.

Cook JA, Edwards SV, Lacey EA, Guralnick RP, Soltis PS, Soltis DE, Welch CK, Bell KC, Galbreath KE, Himes C, Allen JM, Heath TA, Carnaval AC, Cooper KL, Liu M, Hanken J, Ickert-Bond S. Natural history collections as emerging resources for innovative education. Bioscience. 2014;64:725-34.

Cunningham JA. The use of photogrammetric fossil models in palaeontology education. Evol Educ Outreach. 2021;14:2-7.

Freeman S, Eddy SL, McDonough M, Smith MK, Okoroafor N, Jordt H, Wenderoth MP. Active learning increases student performance in science, engineering, and mathematics. Proc Natl Acad Sci USA. 2014;111:8410-5.

Grant CA, MacFadden BJ, Antonenko P, Perez VJ. 3-D fossil for K-12 education: a case example using the giant extinct shark Carcharocles megalodon. Paleontolog Soc Papers. 2017;22:197-209.

Haak DC, HilleRisLambers J, Pitre E, Freeman S. Increased structure and active learning reduce the achievement gap in introductory biology. Science. 2011;332:1213-6.

Handelsman J, Ebert-May D, Beichner R, Bruns P, Chang A, DeHaan R, Gentile J, Lauffer S, Stewart J, Tilghman SM, Wood WB. Scientific teaching. Science. 2004;304:521-2. 
Honey M, Pearson G, Schweingruber H, editors. STEM integration in K-12 education: status, prospects, and an agenda for research. Washington, DC: National Academies Press; 2014.

Hughes BE. Coming out in STEM: factors affecting retention of sexual minority STEM students. Sci Adv. 2018:4:eaao6373.

Jarrett O, Burnley P. Engagement in authentic geoscience research: evaluation of research experiences of undergraduates and secondary teachers. J Geosci Educ. 2003;51:85-90.

Kelley $\mathrm{PH}$, Visaggi CC. Learning paleontology through doing: integrating an authentic research project into an invertebrate paleontology course. In: Lockwood R, Yacobucci MM, editors. Teaching Paleontology in the 21st Century. Cambridge: Cambridge University Press; 2012. p. 181-97.

Kontra C, Lyons DJ, Fischer SM, Beilock SL. Physical experience enhances science learning. Psychol Sci. 2015;26:737-49.

Lillian M. Spencer, Blaire Van Valkenburgh, John M. Harris. Taphonomic Analysis of Large Mammals Recovered from the Pleistocene Rancho La BreaTar Seeps. Paleobiology. Autumn. 2003;29(4):561-575.

Maltese $\mathrm{A}$, Melki C, Wiebke $\mathrm{H}$. The nature of experiences responsible for the generation and maintenance of interest in STEM. Sci Educ. 2014;98:937-62

Martin LD, Gilbert BM. Excavations at Natural Trap Cave. Trans Nebraska Acad Sci. 1978:6:107-16.

Meachen JA, Brannick AL, Fry T. Extinct Beringian wolf morphotype found in the continental U.S. has implications for wolf migration and evolution. Ecol Evol. 2016:6:3430-8.

Meyer XS, Capps DK, Crawford BA, Ross R. Using inquiry and tenets of multicultural education to engage Latino English-language learning students in learning about geology and the nature of science. J Geosci Educ. 2012;60:212-9.

National Research Council. A framework for K-12 science education: practices, Crosscutting Concepts, and Core Ideas. Washington DC: The National Academies Press; 2012.

Nazier G. Science and engineering professors: Why did they choose science as a career? Sch Sci Math. 1993;93:321-4.

Next Generation Science Standards: for states, by states. Washington DC: The National Academies Press. 2013. http://www.nextgenscience.org/. Accessed 12 April 2021.

Olcott A. Integrating Active Learning into Paleontology Classes (Elements of Paleontology). Cambridge: Cambridge University Press; 2018.
Potvin P, Hasni A. Analysis of the decline in interest towards school science and technology from grades 5 through 11. J Sci Educ Technol. 2014;23:784-802

Rushin CJ. Interpretive and paleontologic values of Natural Trap Cave, Bighorn Mountains, Wyoming. M.S.: University of Montana; 1973.

Sadler PM, Sonnert G, Hazari Z, Tai RH. Stability and volatility of STEM career interest in high school: a gender study. Sci Educ. 2012:96:411-27.

Schleicher A. PISA 2018 insight and interpretations. Paris: OECD Publishing; 2019.

Smith-Doerr L, Alegria SN, Sacco T. How diversity matters in the U.S. Science and Engineering Workforce: a critical review considering integration in teams, fields, and organizational contexts. Engag Sci Technol Soc. 2017;3:139-53.

Suarez AV, Tsutsui ND. The value of museum collections for research and society. Bioscience. 2004;54:66-74.

TIMSS 2019 U.S. Highlights Web Report. U.S. Department of Education. Institute of Education Sciences, National Center for Education Statistics. https://nces.ed.gov/timss/results19/index.asp. Accessed 12 April 2021.

Tomiya S, Meachen JA. Postcranial diversity and recent ecomorphic impoverishment of North American gray wolves. Biol Lett. 2018;14:e20170613.

Visaggi C. Equity, culture, and place in teaching paleontology: student-centered pedagogy for broadening participation (elements of paleontology). Cambridge: Cambridge University Press; 2020

Wang MT, Degol JL. Gender gap in science, technology, engineering, and mathematics (STEM): current knowledge, implications for practice, policy, and future directions. Educ Psychol Rev. 2017;29:119-40.

Wang XM, Martin LD. Late Pleistocene, paleoecology and large mammal taphonomy, Natural Trap Cave, Wyoming. Nat Geogr Res Explor. 1993;9:422-35.

Winstone N, Millward L. Reframing perceptions of the lecture from challenges to opportunities: embedding active learning and formative assessment into the teaching of large classes. Psychol Teach Rev. 2012;18:31-41.

\section{Publisher's Note}

Springer Nature remains neutral with regard to jurisdictional claims in published maps and institutional affiliations.
Ready to submit your research? Choose BMC and benefit from:

- fast, convenient online submission

- thorough peer review by experienced researchers in your field

- rapid publication on acceptance

- support for research data, including large and complex data types

- gold Open Access which fosters wider collaboration and increased citations

- maximum visibility for your research: over $100 \mathrm{M}$ website views per year

At $\mathrm{BMC}$, research is always in progress.

Learn more biomedcentral.com/submissions 